\title{
Identification of novel interaction partners for Vlgr1b/GPR98 - a key component of the periciliary Usher syndrome protein network in photoreceptor cells
}

\author{
B Knapp ${ }^{1 *}$, SJ Letteboer ${ }^{2,3,5}$, E van Wijk ${ }^{2,4,5,6}$, K Boldt $^{7}$, M Ueffing $^{7}$, H Kremer $^{2,4,5,6}$, R Roepman ${ }^{2,3,5}$, U Wolfrum ${ }^{1}$
}

From First International Cilia in Development and Disease Scientific Conference (2012)

London, UK. 16-18 May 2012

The human Usher syndrome (USH) is the most common form of combined hereditary deaf-blindness. Three clinical subtypes (USH1-3) are differentiated based on severity, age of onset and progression of the symptoms. Mutations in the GPR98 gene encoding the USH2C protein Vlgr1b or GPR98 cause USH2, the most common form of USH. The G-protein coupled receptor Vlgr1b was previously identified as a component of the periciliary USH protein network, crucial for ciliary cargo transport in photoreceptors. Nonetheless, the exact role of Vlgr $1 \mathrm{~b}$ in this and other cellular processes remains to be elucidated. To learn more about its involvement in cellular functions we searched for novel interaction partners of Vlgr1b. For this we adopted yeast-2-hybrid screens of human and bovine cDNA libraries and tandem affinity purification followed by mass spectrometry. Our approaches revealed several heterogenous proteins as putative binding partners of the Vlgr1b C-terminus including diverse scaffolding proteins and cytoskeleton elements that provide a link to vesicle transport. In addition, coactivators of nuclear receptors and transcription factors were found, proposing a putative relation to gene regulation. The present data suggests the participation of Vlgr1b in several different cellular functions not only at cilia but also at synapses. Furthermore, a potential molecular link between USH and the Joubert syndrome, another human ciliopathy, was found. The present study not only adds new branches to the Vlgr1b/ GPR98 rooted protein network and the entire USH protein interactome but provides also novel insights into the

\footnotetext{
* Correspondence: knappb@students.uni-mainz.de

${ }^{1}$ Cell and Matrix Biology, Institute of Zoology, Johannes Gutenberg-University of Mainz, Germany

Full list of author information is available at the end of the article
}

cellular function and the pathomechanisms underlying USH type 2.

\section{Author details}

${ }^{1}$ Cell and Matrix Biology, Institute of Zoology, Johannes Gutenberg-University of Mainz, Germany. ${ }^{2}$ Dept of Human Genetics, Nijmegen Centre for Molecular Life Sciences, Nijmegen, Netherlands. ${ }^{3}$ Institute for Genetic and Metabolic Disease, Nijmegen Centre for Molecular Life Sciences, Nijmegen, Netherlands. ${ }^{4}$ Dept of Otorhinolaryngology, Head and Neck Surgery, Nijmegen Centre for Molecular Life Sciences, Nijmegen, Netherlands. ${ }^{5}$ Nijmegen Centre for Molecular Life Sciences, Nijmegen, Netherlands. ${ }^{6}$ Donders Institute for Brain, Cognition and Behaviour, Radboud University Nijmegen Medical Centre, Nijmegen, Netherlands. ${ }^{7}$ Medical Proteome Center, Centre for Ophthalmology, University of Tuebingen, Germany.

Published: 16 November 2012

doi:10.1186/2046-2530-1-S1-P29

Cite this article as: Knapp et al:: Identification of novel interaction partners for Vlgr1b/GPR98 - a key component of the periciliary Usher syndrome protein network in photoreceptor cells. Cilia 2012 1(Suppl 1): P29.

Submit your next manuscript to BioMed Central and take full advantage of:

- Convenient online submission

- Thorough peer review

- No space constraints or color figure charges

- Immediate publication on acceptance

- Inclusion in PubMed, CAS, Scopus and Google Scholar

- Research which is freely available for redistribution

\section{Biomed Central}

(c) 2012 Knapp et al; licensee BioMed Central Ltd. This is an Open Access article distributed under the terms of the Creative Commons Attribution License (http://creativecommons.org/licenses/by/2.0), which permits unrestricted use, distribution, and reproduction in any medium, provided the original work is properly cited. 